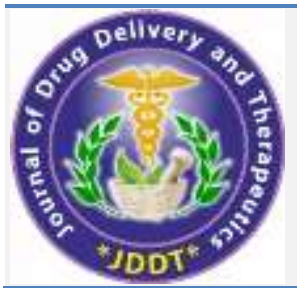

Access Full Text Article

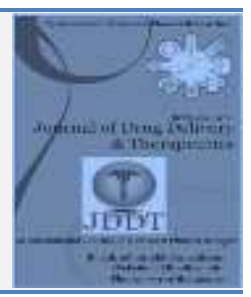

Research Article

\title{
Development and characterization of effervescent floating tablet of famotidine for treatment of peptic ulcer
}

\author{
Shilpi Sahu, Vivek Jain, Sunil Kumar Jain, Pushpendra Kumar Khangar* \\ Adina Institute of Pharmaceutical Science, NH86A, Lahdara, Sagar, MP 470001
}

\section{Article Info:}

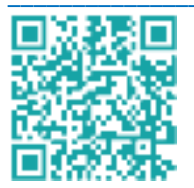

\section{Article History:}

Received 11 October 2021 Reviewed 19 November 2021 Accepted 30 November 2021 Published 06 December 2021

\section{Cite this article as:}

Sahu S, Jain V, Jain SK, Khangar PK, Development and characterization of effervescent floating tablet of famotidine for treatment of peptic ulcer, Journal of Drug Delivery and Therapeutics. 2021; 11(5-s):119123

DOI: http://dx.doi.org/10.22270/jddt.v11i5-s.5118

\section{Abstract}

Floating drug delivery systems (FDDS) are utilized to target drug discharge in the stomach or to the upper parts of intestine. Famotidine has been the most extensively used drug for the management of peptic ulcer for various decades. The current study concerns the development and evaluation of floating tablets of famotidine which, after oral administration, are planned to extend the gastric residence time, enhance drug bioavailability and aim the gastric ulcer. A FDDS was expanded using gas-forming agents, like sodium bicarbonate, citric acid and hydrocolloids, like hydroxypropyl methylcellulose (HPMC) and carbopol 934P. The prepared tablets were evaluated in terms of their precompression parameters, physical characteristics, buoyancy, buoyancy lag-time, in vitro release, and swelling index. The formulations were optimized for the different viscosity grades of HPMC, carbopol 934P and its concentrations and combinations. The consequences of the in vitro release studies demonstrated that the optimized formulation (F6) could sustain drug release (98\%) for $24 \mathrm{~h}$ and remain buoyant for $24 \mathrm{hr}$. Optimized formulation (F6) showed no considerable change in physical appearance, drug content, total buoyancy time or in vitro dissolution study after storage at $40^{\circ} \mathrm{C} / 75 \% \mathrm{RH}$ for 3 months. Lastly the tablet formulations establish to be economical and may conquer the draw backs associated with the drug during its absorption.

Keywords: Famotidine, Floating drug delivery system, Hydrocolloids, Gastric residence time.

\footnotetext{
*Address for Correspondence: Pushpendra Kumar Khangar, Adina Institute of Pharmaceutical Science, NH86A, Lahdara, Sagar, MP 470001
}

\section{INTRODUCTION}

The oral route of drug administration is the most suitable and frequently used technique of drug delivery. However, oral route has numerous physiological difficulties, counting an unpredictable gastric emptying rate that differ from person to person, a short GIT transit time (8-12 h), and the survival of an absorption window in the upper small intestine for numerous drugs ${ }^{1,2}$. These complexities have prompted researchers to plan a drug delivery system which can reside in the stomach for extended and unsurprising period $^{3,4}$. Attempts are being made to expand a controlled drug delivery system, which can give therapeutically effectual plasma drug concentration for a longer era, thereby dropping the dosing frequency and minimizing variations in plasma drug concentration at steady-state by distributing the drug in a controlled and reproducible way5. Diverse methodologies have been accounted in the text to raise the gastric retention of drugs, like hydrodynamically balanced systems, intra-gastric floating systems, extendable or expandable and super porous biodegradable hydrogel systems ${ }^{6}$. The FDDS consequence in long lasting intra-gastric buoyancy which may not only give a sustained site of specific therapeutic action but also may lead to a reduction in side effects and improved patient compliance ${ }^{7}$. Helicobacter pylori is a widespread human specific pathogen, which is ISSN: 2250-1177 now supposed to be the causative bacterium for chronic gastritis, peptic ulcer and adenocarcinoma, one of the most ordinary forms of cancer in humans and its abolition needs elevated concentration of drug within the gastric mucosa for long duration ${ }^{8,9}$. Thus, fast dissolving oral delivery system is expected to enhance bioavailability of all drugs which are well absorbed from the GI tract ${ }^{10}$. Effervescent FDDS generate gas $\left(\mathrm{CO}_{2}\right)$, thus decrease the density of the system and stay buoyant in the stomach for a extended period of time and released the drug gradually at a desired rate ${ }^{11,12}$ Famotidine, a competitive histamine $\mathrm{H}_{2}$-receptor antagonist is employ to treat GIT disorders such as gastric or duodenal ulcer, gastroesophageal reflux disease, and pathological hypersecretory conditions. Famotidine inhibits numerous of the iso-enzymes of the hepatic CYP450 enzyme system. Other actions of famotidine include enhance in gastric bacterial flora such as nitrate-reducing organisms ${ }^{13}$. Famotidine is extensively employed as the treatment of peptic ulcer disease and gastroesophageal reflux disease. Famotidine attaches competitively to $\mathrm{H}_{2}$ - receptors located on the basolateral membrane of the parietal cell, blocking histamine affects. This competitive inhibition consequences in abridged basal and nocturnal gastric acid secretion and a decrease in gastric volume, acidity, and amount of gastric acid released in response to stimuli including caffeine, 
insulin, food, betazole and pentagastrin ${ }^{14}$. The short bioavailability (40-45\%), short biological half life (2.5-4.0 hours) and connected unfavorable effects like headache, diarrhoea, dizziness, and anorexia etc, which may also shows toxic effect in extend employ. To conquer these disadvantages, in the current examination effervescent floating tablets of dissimilar formulation were developed with an objective of achieving 24 hrs floating and drug release time. This advance also reduces the surplus side effects of the drug, the tablet remain buoyant for an extended period on the gastric contents, showing a prolonged gastric residence time, consequence in sustained drug release and reliable blood levels of drug.

\section{MATERIAL AND METHODS}

\section{Material}

Famotidine was received as a gift sample from Vasavaa Pharmaceuticals Pvt Ltd., Hyderabad. Hydroxypropyl methylcellulose K4M and K15M, carbopol 934P were purchased from Loba Chem. Pvt. Ltd, Mumbai. Magnesium stearate, hydrochloric acid, sodium bicarbonate and citric acid anhydrous were purchased from S.D. Fine-Chem Ltd, Ahmedabad, India. Polyvinyl pyrrolidone K-30 (PVP K-30) was procured from Ottokemi, Mumbai, India. Lactose and purified talc were purchased from E. Merck (India) Ltd., Mumbai. Double distilled water was prepared freshly and used whenever required. All the chemicals used in this work were of analytical grade.

\section{Methods}

\section{Preformulation study}

\section{Melting point determination}

Melting point of famotidine was established by open capillary method.

\section{Solubility studies}

Solubility is defined in quantitative expressions as the concentration of solute in a saturated solution at a convinced temperature and in qualitative terms it may be defined as the spontaneous interaction of two or more materials to form a $\mathrm{v} / \mathrm{v}$ homogeneous molecular dispersion ${ }^{15}$. Solubility of famotidine was determined in different solvents. Famotidine (10 mg) was suspended in $10 \mathrm{ml}$ of dissimilar solvents in tightly closed test tubes. These tubes were shaken for about 72 hrs using Wrist action Shaker (Yorco, New Delhi) and solubility was determined.

\section{Determination of $\lambda \max$}

A solution of famotidine containing the concentration $50 \mu \mathrm{g} / \mathrm{ml}$ was prepared in $0.1 \mathrm{~N} \mathrm{HCl}$ solution and UV spectrum was taken using Shimadzu (model 1601) double beam spectrophotometer. The solution was scanned in the range of 200-400 nm.

\section{Preparation calibration curve}

Exactly weighed $10 \mathrm{mg}$ of drug was dissolved in $10 \mathrm{ml}$ of $0.1 \mathrm{~N} \mathrm{HCl}$ solution in $10 \mathrm{ml}$ of volumetric flask. The resulted solution $1000 \mu \mathrm{g} / \mathrm{ml}$ and from this solution $1 \mathrm{ml}$ pipette out and transfer into $10 \mathrm{ml}$ volumetric flask and volume make up with $0.1 \mathrm{~N} \mathrm{HCl}$ solution. Prepare suitable dilution to make it to a concentration range of $12.5-200 \mu \mathrm{g} / \mathrm{ml}$. The spectrum of this solution was run in $200-400 \mathrm{~nm}$ range in U.V. spectrophotometer (model 1601). Linearity of standard curve was assessed from the square of correlation coefficient (r2) which determined by least-square linear regression analysis.

\section{FTIR spectroscopy}

Infrared spectrum of any compound gives information about the groups present in that particular compound. IR spectrum of famotidine was recorded using Perkin Elmer Instrument spectrum one (model) using $\mathrm{KBr}$ pellets. Various peaks in IR spectra were interpreted for different groups and were matched with reference IR spectra ${ }^{16}$.

\section{Pre compression evaluation}

Flow properties and compressibility properties of powder mixture were evaluated by measurement of bulk density, tapped density, angle of repose, carr's index, and hausner's ratio.

\section{Angle of repose $(\theta)$}

The angle of repose was determined by using fixed funnel method. The physical mixtures of drug with different excipients were prepared and the accurately weighed drug powder or its physical mixture was taken in a funnel. The height of the funnel was adjusted in such a way that the tip of the funnel just touches the apex of the heap of the drug powder. The powder was allowed to flow through the funnel freely onto surface. The angle of repose was calculated using the following equation.

$$
\theta=\tan -1(\mathrm{~h} / \mathrm{r})
$$

Where, $\mathrm{h}$ and $\mathrm{r}$ are the height and radius of the powder cone respectively.

\section{Bulk density}

Both loose bulk density (LBD) and tapped density (TBD) were determined were calculated using the following formulas.

$$
\text { LBD = Powder weight/volume of the packing }
$$

TBD = Powder weight /tapped volume of the packing

\section{Compressibility index}

The compressibility index of the granules was determined by Carr's compressibility index.

$$
\text { Carr's index }(\%)=[(\mathrm{TBD}-\mathrm{LBD}) / \mathrm{TBD}] \times 100 \text {. }
$$

\section{Hausner's ratio}

Hausner's ratio is an indirect index of ease of measuring the powder flow. It was calculated by the following formula17-19.

$$
\text { Hausner's ratio }=\text { Tapped density/Bulk density. }
$$

\section{Preparation of floating tablets of famotidine}

The ingredients were weighed precisely and mixed scrupulously. Granulation was done with a solution of PVP K30 in adequate isopropyl alcohol. The granules (40 mesh) were dried in conventional hot air oven at $45^{\circ} \mathrm{C}$. Drying of the granules was stopped when the sample taken from the oven reached a loss on drying (LOD) value of 0.5 to $1.5 \%$, as measured by a moisture balance at $105^{\circ} \mathrm{C}$. The dried granules were sized through 40/60 mesh, lubricated with magnesium stearate $(2 \% \mathrm{w} / \mathrm{w})$ and purified talc $(1 \% \mathrm{w} / \mathrm{w})$, aerosil $(1 \% \mathrm{w} / \mathrm{w})$ and then compressed on a single punch tablet machine. The tablets were off white, round and flat. The hardness of the tablets was kept constant. Six formulations were prepared and coded them from F1 to F6. The detail of composition of each formulation is given in Table 1. 
Table 1: Formulation composition of famotidine gastro retentive tablets

\begin{tabular}{|c|c|c|c|c|c|c|}
\hline Ingredients* (In mg per tablet) & Fl & F2 & F3 & F4 & F5 & 40 \\
\hline Famotidine & 40 & 40 & 40 & 40 & 40 \\
\hline HPMC (K4M) & 100 & 75 & 50 & - & 50 & 25 \\
\hline HPMC(KI5M) & - & - & - & - & 50 & 50 \\
\hline Carbopol 934P & - & - & - & 50 & - & 25 \\
\hline Citric acid & 35 & 35 & 35 & 35 & 35 & 35 \\
\hline Sodium bicarbonate & 70 & 70 & 70 & 70 & 70 & 70 \\
\hline PVP K-30 & 15 & 15 & 15 & 15 & 15 & 15 \\
\hline MCC & 124 & 149 & 174 & 174 & 124 & 4 \\
\hline Talc & 4 & 4 & 4 & 4 & 4 & 4 \\
\hline Magnesium stearate & 8 & 8 & 8 & 8 & 4 & 4 \\
\hline Aerosil & 4 & 4 & 4 & 4 & 4 & 400 \\
\hline
\end{tabular}

\section{Evaluation of tablets}

All the tablets were evaluated for following dissimilar parameters which includes;

\section{General Appearance}

Five tablets from diverse batches were arbitrarily selected and organoleptic properties such as color, odor, taste, shape, were evaluated. Appearance was judged visually. Very good $(+++)$, good $(++)$, fair $(+)$ poor $(-)$, very poor $(-)$.

\section{Thickness and diameter}

Thickness and diameter of tablets were established using Vernier caliper. Five tablets from each batch were used, and an average value was calculated.

\section{Hardness}

For each formulation, the hardness of five tablets was determined using the Monsanto hardness tester (Cadmach).

\section{Friability}

The friability of a sample of 10 tablets was measured using a friability tester (Electro Lab).Ten tablets were weighed, rotated at $25 \mathrm{rpm}$ for 4 minutes. Tablets were reweighed after deduction of fines (dedusted) and the percentage of weight loss was calculated.

\section{Uniformity of weight}

Twenty tablets were randomly selected from each batch independently weighed, the average weight and standard deviation of 20 tablets was calculated.

\section{Drug content}

Twenty tablets were occupied and amount of drug present in each tablet was indomitable. The tablets were crushed in a mortar and the powder equivalent to $100 \mathrm{mg}$ of drug was transferred to $100 \mathrm{ml}$ standard flask. The powder was dissolved in $50 \mathrm{ml}$ of $0.1 \mathrm{~N} \mathrm{HCl}$ solution and made up to volume with of $0.1 \mathrm{~N} \mathrm{HCl}$ solution. The sample was mixed scrupulously and filtered through a $0.45 \mu$ membrane filter. The filtered solution was diluted suitably and analyzed for drug content by UV spectrophotometer at a $\lambda \max$ of $265 \mathrm{~nm}$ using of $0.1 \mathrm{~N} \mathrm{HCl} \mathrm{solution} \mathrm{as} \mathrm{blank} \mathrm{k}^{20,21}$.

\section{In vitro buoyancy studies}

In vitro buoyancy was indomitable by floating lag time as per the method described by Rosa et al22. The tablets were independently in a $100 \mathrm{ml}$ glass beaker containing simulated gastric fluid (SGF), pH 1.2 as per USP. The time essential for the tablet to enhance to the outside and float was determined as floating lag time. The experiments were performed in triplicate. Total floating times were calculated during in vitro dissolution studies.

\section{Dissolution rate studies}

The release rate of famotidine from floating tablets was decided using (USP) Dissolution Testing Apparatus 2 (paddle method). The dissolution test was executed using $900 \mathrm{ml}$ of $0.1 \mathrm{~N}$ hydrochloric acid, at $37 \pm 0.5^{\circ} \mathrm{C}$ and $50 \mathrm{rpm}$. A sample $(10 \mathrm{ml})$ of the solution was withdrawn from the dissolution apparatus hourly and the samples were replaced with fresh dissolution medium. The samples were filtered through a $0.45 \mu$ membrane filter and diluted to a suitable concentration with $0.1 \mathrm{~N}$ hydrochloric acid. Absorbance of these solutions was measured at $265 \mathrm{~nm}$ using a UV/Visible spectrophotometer. The percentage drug release was plotted against time to determine the release profile.

\section{Stability studies}

The promising formulation was tested for a period of 3 month at $40^{\circ} \mathrm{C}$ with $75 \% \mathrm{RH}$, for their drug content and other parameters.

\section{RESULT AND DISCUSSION}

The melting point of famotidine was established to be 163 $165^{\circ} \mathrm{C}$. The $\lambda \max _{\max }$ of famotidine was established to be $265 \mathrm{~nm}$ by using U.V. spectrophotometer (model 1601) in linearity range $12.5-200 \mu \mathrm{g} / \mathrm{ml} \mathrm{Fig.1.} \mathrm{Famotidine} \mathrm{is} \mathrm{freely} \mathrm{soluble} \mathrm{in} \mathrm{di-}$ methylformamide, glacial acetic acid, slightly soluble in methanol and practically insoluble in ethanol, chloroform. In FTIR spectra, strong bands were observed at $1638 \mathrm{~cm}^{-1}$, $1534 \mathrm{~cm}^{-1}, 2935.81 \mathrm{~cm}^{-1}, 1331 \mathrm{~cm}^{-1}, 3399.91 \mathrm{~cm}^{-1}$ and 1320 $\mathrm{cm}^{-1}$, which confirms the presence of imine, amine and sulfonyl group in the compound, as shown in Fig. 2, Hence it proves the identity of pure drug. Tablet powder blend was subjected to different pre-formulation parameters Table 2 . 
The angle of repose values indicates that the powder blend has good flow properties. The bulk density and tapped density of all the formulations was found to be in the range of 0.431 to 0.510 and 0.587 to $0.623\left(\mathrm{gm} / \mathrm{cm}^{3}\right)$ showing the powder has good flow properties. The compressibility index and hauser's ratio of all the formulations was found to be ranging between 18.12 to 28.78 and 0.065 to 0.154 which shows that the powder has superior flow properties. Famotidine tablet quality control tests such as weight variation, hardness, friability, thickness, drug content and drug release studies in dissimilar media were performed on the compression tablet. All the parameters such as weight variation, hardness, friability, thickness and drug content were established to be within limits Table 3. Optimized formulation F6 remained floatable in the stomach for 24 hours and give the highest released $98.0 \%$ at 24 hours. The optimized floating tablets (F6) were chosen for stability study on the basis of in vitro buoyancy and in vitro drug dissolution studies. The tablets were examined at $40^{\circ} \mathrm{C} / 75 \% \mathrm{RH}$ for 3 months. From the data, the formulation is establish to be stable beneath the conditions mentioned before since there was no considerable change in the \% amount of drug content (Table 4). Thus, it was establish that the floating tablets of famotidine (F6) were stable under these storage conditions for at least 3 months.

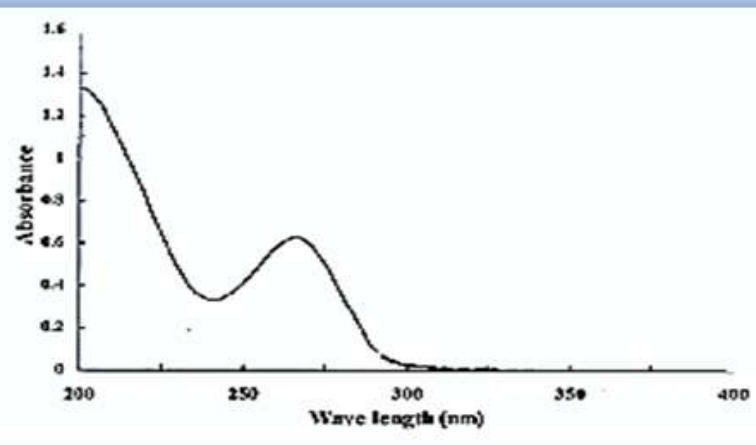

Figure 1 U.V. Spectra of Pure Drug (Famotidine)

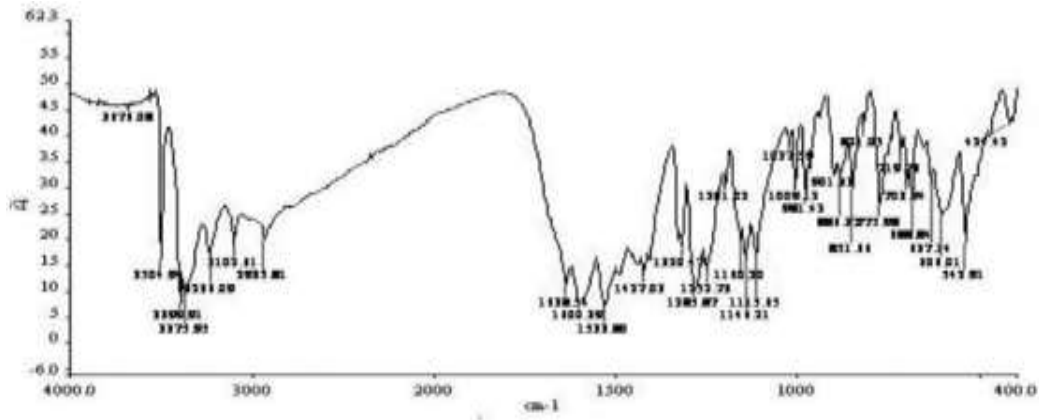

Figure 2 IR analysis of famotidine

Table 2: Result of pre-compression properties of granules of famotidine

\begin{tabular}{|c|c|c|c|c|c|}
\hline Formulation & $\begin{array}{c}\text { Angle of } \\
\text { Repose } \\
(\theta)\end{array}$ & $\begin{array}{c}\text { Bulk } \\
\text { density }\left(\mathrm{gm} / \mathrm{cm}^{3}\right)\end{array}$ & $\begin{array}{c}\text { Tapped } \\
\text { density }\left(\mathrm{gm} / \mathrm{cm}^{3}\right)\end{array}$ & $\begin{array}{l}\text { Carr's } \\
\text { index }\end{array}$ & $\begin{array}{c}\text { Hauser's } \\
\text { ratio }\end{array}$ \\
\hline F1 & $28.13^{\circ}$ & 0.486 & 0.614 & 18.12 & 0.154 \\
\hline F2 & $25.45^{\circ}$ & 0.468 & 0.623 & 19.43 & 0.142 \\
\hline F3 & $28.67^{\circ}$ & 0.431 & 0.591 & 22.10 & 0.065 \\
\hline $\mathrm{F} 4$ & $31.23^{\circ}$ & 0.437 & 0.623 & 28.78 & 0.121 \\
\hline F5 & $25.41^{\circ}$ & 0.483 & 0.587 & 26.53 & 0.088 \\
\hline F6 & $24.58^{\circ}$ & 0.510 & 0.610 & 21.32 & 0.112 \\
\hline
\end{tabular}

Table 3: Results of post compression properties of famotidine floating tablets

\begin{tabular}{|c|c|c|c|c|c|}
\hline F. code & $\begin{array}{c}\text { Thickness } \\
\mathbf{( m m )}\end{array}$ & $\begin{array}{c}\text { Hardness } \\
\mathbf{( k g / \mathbf { c m } ^ { 2 } )} \\
\mathbf{n = 3}\end{array}$ & $\begin{array}{c}\text { Weight variation (mg) } \\
\mathbf{n = 3}\end{array}$ & $\begin{array}{c}\text { Friability (\%) } \\
\mathbf{n}=3\end{array}$ & $\begin{array}{c}\text { Drug content (\%) } \\
\mathbf{n}=3\end{array}$ \\
\hline F1 & $3.0 \pm 0.01$ & 5.5 & $400 \pm 0.25$ & 0.481 & 99.12 \\
\hline F2 & $2.9 \pm 0.02$ & 6.0 & $399 \pm 0.30$ & 0.57 & 97.34 \\
\hline F3 & $3.1 \pm 0.03$ & 5.5 & $398 \pm 0.28$ & 0.61 & 100.12 \\
\hline F4 & $2.9 \pm 0.02$ & 5.5 & $404 \pm 0.66$ & 0.65 & 101.34 \\
\hline F5 & $3.0 \pm 0.01$ & 6.0 & $404 \pm 0.22$ & 0.31 & 99.34 \\
\hline F6 & $2.9 \pm 0.02$ & 5.5 & $402 \pm 0.44$ & 0.74 & 100.12 \\
\hline
\end{tabular}


Table 4: Stability study $\left(40{ }^{\circ} \mathrm{C} / 75 \% \mathrm{RH}\right)$ of optimized formulation (F6)

\begin{tabular}{|c|c|c|c|}
\hline Parameters & $\mathbf{1}^{\text {st }}$ month & $\mathbf{2}^{\text {nd }}$ month & $\mathbf{3}^{\text {rd }}$ month \\
\hline Physical appearance & $\begin{array}{c}\text { Off white. } \\
\text { smooth. flat faced }\end{array}$ & $\begin{array}{c}\text { Off white. } \\
\text { smooth. flat faced } \\
\text { smooth. flat faced }\end{array}$ & $402 \pm 0.44$ \\
\hline Weight variation(mg) & $402 \pm 0.44$ & $402 \pm 0.44$ & 5.3 \\
\hline Hardness (kg/cm) & 5.5 & 5.4 & 0.75 \\
\hline Friability (\%) & 0.4 & 0.73 & 98.12 \\
\hline Drug content (\%) & 100.12 & 99.08 & 97.00 \\
\hline
\end{tabular}

\section{CONCLUSION}

Famotidine floating tablets were successfully formulated by floating technique. The optimized formulation (F6) was selected on the basis of in vitro buoyancy and in vitro drug release. The addition of gel forming agent and gas generating agent was essential to attain in vitro buoyancy. The consequences of the in vitro drug release study demonstrated that the optimized formulation (F6) sustained the drug release (98\%) up to $24 \mathrm{hrs}$. Optimized formulation (F6) does not demonstrate any considerable change in physical appearance, floating properties and drug release after storage at $40^{\circ} \mathrm{C} / 75 \% \mathrm{RH}$ and stable for 3 months.

\section{REFERENCES}

1. Agyilirah GA, Green M, Ducret R. Evaluation of the gastric retention properties of a crosslinked polymer coated tablet versus those of a non-disintegrating tablets. Int J Pharm 1991; 75:241-247. https://doi.org/10.1016/0378-5173(91)90198-W

2. Hoffman F, Pressman JH, Code CF. Controlled entry of orally administered drugs: physiological considerations. Drug Dev Ind Pharm1983; 9:1077-1085.

https://doi.org/10.3109/03639048309046314

3. Deshpande AA, Shah NH, Rhodes CT. Controlled release drug delivery systems for prolonged gastric residence: an overview. Drug Dev Ind Pharm 1996; 22:531-539. https://doi.org/10.3109/03639049609108355

4. Hwang SJ, Park H, Park K. Gastric retentive drug delivery systems. Crit Rev Ther Drug 1998; 15:243-248. https://doi.org/10.1615/CritRevTherDrugCarrierSyst.v15.i3.20

5. Sood RP. Design of controlled release delivery systems using modified pharmacokinetic approach: a case study for drugs having a short elimination half life and a narrow therapeutic index. Int J Pharm 2003; 261:27-41.

https://doi.org/10.1016/S0378-5173(03)00267-9

6. Singh N, Kim KH. Floating drug delivery systems: an approach to oral controlled drug delivery via gastric retention. J Control Release 2000; 63:235-259. https://doi.org/10.1016/S01683659(99)00204-7

7. Soppimath KS, Kulkarni RA, Rudzinski WE. Microspheres as floating drug delivery systems to increase gastric retention of drugs. Drug Met Rev 2001; 33:149-160.

https://doi.org/10.1081/DMR-100104401

8. Rang HP, Dale M, Ritter JM, Flower RJ. Rang and Dale's. Pharmacology, 6th ed. pp. 402.
9. Laurence LB, Keith LP, Donald KB. Goodmann and Gilmann. The Pharmacological Basis of Therapeutics. 11th edition, 2006, pp. 1051.

10. Patil SC, Payghan SA, Disouza JI. Formulation and evaluation of oral disintegrating tablet of lornoxicam. Int J Pharm \& Bio Archives 2011; 2(5):1518-1523.

11. Klausner EA, Lavy E, Friedman M, Hoffman A. Expandable gastroretentive dosage form. J Control Rel 2003; 90:143-162. https://doi.org/10.1016/S0168-3659(03)00203-7

12. Singh BN, Kim HK. Floating drug delivery systems: an approach to oral controlled drug delivery via gastric retention. J Control Rel 2000; 63:235-59. https://doi.org/10.1016/S01683659(99)00204-7

13. Al-Omar MA, Al-Mohizea AM. Famotidine, analytical profile. In: Brittain HG, editor. Profiles of drug substances, excipients and related methodology. Burlington: Academic Press; 2009, pp. 115-151. https://doi.org/10.1016/S1871-5125(09)34003-0

14. Muzib YI, Ch Rekha. Development and evaluation of mineral oil entrapped emulsion gel beads of famotidine. Int J Pharmacol Technol 2011; 3(2):83-90.

15. Babu VR, Areefulla SH, Mallikarjun V, et al., Solubility and dissolution enhancement: an overview. J Pharm Res 2010; 3(1):141-145.

16. Indian Pharmacopoeia, Government of India ministry of health and family welfare, The controller of Publication, Delhi, 4 th ed, 1996.

17. Sinko PJ, Physical Pharmacy and Pharmaceutical Sciences, Lippincott Williams and Wilkins, 5th Edition, 2006.

18. Chein YW. Novel drug delivery systems, Marcel Dekker, INC, 2nd edition, 1992, pp. 140.

19. Liberman HA, Lachman L, Schwartz JB. Pharmaceutical dosage forms: Tablets, 3rd edition, Marcel Dekker, New York, 1990.

20. Indian Pharmacopoeia, The Controller of Publications: Delhi, Vol. II, 1996; pp: 734-36.

21. Banker GS, Anderson NR. In The Theory and Practice of Industrial Pharmacy, Lachmann L, Liberman HA, Kaing JL. Eds. Varghese Publishing House: Bombay, 1987; pp. 297-99.

22. Rosa M, Zia H, Rhodes T. Dosing and testing in vitro of a bioadhesive and floating drug delivery system for oral application. Int J Pharm 1994; 105:65-70. https://doi.org/10.1016/0378-5173(94)90236-4 